\title{
Tannins and their Effect on Production Efficiency of Ruminants
}

\author{
Andrej MERGEDUŠ ${ }^{1 \star}$, Martina PŠENKOVÁ², Maksimiljan BRUS ${ }^{1}$, Marjan JANŽEKOVIČ \\ ${ }^{1}$ University of Maribor, Faculty of Agriculture and Life Sciences, Pivola 10, 2311 Hoče, Slovenia \\ ${ }^{2}$ Slovak University of Agriculture in Nitra, Faculty of Agrobiology and Food Resources, Department of Veterinary \\ Disciplines, Tr. A. Hlinku 2, 94976 Nitra, Slovak Republic
}

\begin{abstract}
In the recent years, numerous publications have analysed the efficiency of phytogenic feed additives, plant-based supplements, in animal nutrition for improving livestock productivity and the quality of products. Regarding ruminant nutrition, the publications very often focus on the fate of proteins and on productivity as a result of the use of tannins rich plant extracts and plant parts. Most tannin-related studies are concerned with forages, mostly legumes, less is know about tannins extracts. Tannins are phenolic secondary compounds naturally occurring in plants and helping to protect them against herbivores, defend them against pathogens and are participating in energy and nitrogen conservation. Tannins were for a long time considered to be antinutritive compounds to ruminants. Several new systematic studies, associated with analyses of tannins have revealed beneficial roles in animal nutrition and health. New studies more precisely distinguish different groups of tannin. As a result, feed containing tannins, hydrolysable or condensed, has the effect of slowing down the protein digestion, increasing microbial protein synthesis in rumen and reducing methanogenesis. Positive effects on animal health such as the prevention of bloating and multiplication of parasites have also been reported. When fed in proper amounts, tannins may promote higher level of productivity such as higher growth rate, higher milk yield and improved milk quality. Due to their positive role, they are being gradually considered as important nutritive additives in many ruminant feeds.
\end{abstract}

Key words: hydrolysable tannins, condensed tannins, ruminant production

\section{INTRODUCTION}

Ruminants play an important role in the livelihood of farmers and other people, especially in the developing countries. They provide people with meat, milk, wool and other fibers, manure for crop production and cash income from sales of their products (Øsrskov, 1993). They are physiologically adapted to obtain their nourishment from grass and other fibrous forage which humans cannot directly utilize. They can convert low quality, high fiber foodstuffs into the high quality proteines (meat and milk) that are highly desired by people. In addition, these foodstuffs are also rich in minerals, fats and vitamins (Fitzhugh et al., 1978).
Increases in the human population has resulting in a reduction in arable land for agriculture. To meet food consumption, farmers are force to intensify their production. This higher production demands the introduction of highly productive breeds and better quality of feeds (Osuji et al., 1995). Efficiency, especially animal efficiency, also play important role in animal production. In ruminant production the primary input costs is feed, therefore animal feed efficiency has been a key driver of animal production. Maintenance of 'efficient' animals, meaning animal that can in maximum utilize nutrients from feed, is more beneficial to production and cost of production (Krauer, 2009). In order to increase the efficiency of rumen metabolism, many nutritionists 
studied rumen microbial ecosystem manipulation intensively (Pathra and Saxtena, 2010).

A number of chemical feed additives such as antibiotics have been introduced into ruminant nutrition to promote growth, improve feed utilization and decrease methane production (Osuji et al., 1995; Pathra and Saxtena, 2010). Due to the risk of antibiotic resistance being passed on to human pathogens and chemical residues in food, the European Union, in 2006, under the EU Directive EC 1831/2003, banned the use of antibiotics and other chemicals in livestock feeds. This ban has encouraged researchers and scientists to study plant extracts and natural plant compounds as potential natural alternatives for enhancing livestock productivity (Makkar et al., 2009). In recent years, many plants extracts have been evaluated for their ability to modulate rumen microbiome, feed digestion, and rumen fermentation. Some plant compounds have been revealed to have an effect on activity of rumen archaea, protozoa, and specific bacteria populations (Cobellis et al., 2016). The use of tannins in ruminant feed represents one of these alternatives.

The literature about tannins is vast and often contradictory (Piluzza et al., 2014). In the past, tannins were classified as "anti-nutrients" because they can cause a reduction of feed intake and nutrient utilization (Frutos et al., 2004). Recently, there is an increasing awareness of tannins' beneficial roles in animal nutrition and health. Several researchers have reported positive health improvements in ruminants while adding tannins in to the diets. Feeding with tannins resulted in slowing down protein digestion in rumen, increased microbial protein synthesis, decreased methanogenesis and prevention of bloat. The consequences were higher growth rates and milk yields, better milk composition and higher production (Barry and Mcnabb, 1999; Makkar, 2003; Waghorn and McNabb, 2003; Patra and Saxena, 2010). Some studies reported an increase in the levels of beneficial fatty acids (FA) composition in meat and milk, and improves the oxidative stability of meat (Jerónimo et al., 2016). The antimicrobial properties of tannins have opened the possibility of using them to manipulate ruminal microbial activity in a favorable direction (Lamy et al., 2011). Tannins can also have post ruminal benefits, e.g., parasite control (Waghorn and McNabb, 2003). However, tannins may also have negative effects of on animal performance and this fact presents a major restriction on their wider practical application in everyday farming (Mole at al., 1993).

The main purpose of the paper is to present the most important effects of tannins on ruminant production and discuss the theorethical background of those effects.

\section{OCCURRENCE OF TANNINS AND THEIR CHEMICAL COMPOSITION}

Tannins are phenolic secondary compounds with high molecular weight and are chemically very heterogeneous. They can be found in almost $80 \%$ of woody perennial dicotyledonous species and $15 \%$ of annual and herbaceous perennial dicotyledons such as trees, shrubs, legumes, herbs and cereal grains. Many of them are used as animal feed (Mueller-Harvey, 1999; Jerónimo et al., 2016). They can also be found in animal feed involving Acacia, Dichrostachys, Dorycnium, Hedysarum, Leucaena, Lotus, Onobrychis, Populus, Rumex and Salix (Mueller-Harvey, 2006). They are present in seeds, fruits, leaves, wood, bark and roots (Dixon et al., 2005). Tannins are more abundant in plant parts that are most valuable, e.g., new leaves and flowers (Terril et al., 1992). The main reasons for plant tannins synthesis are protection against herbivores, plant defense against pathogens, energy conservation and nitrogen conservation (Waghorn and McNabb, 2003). The level of tannins differ between 2 and $5 \%$ of the fresh weight. Concentration can increase due to pathological conditions, water stress, temperature and nutrient availability (Treutter, 2006).

Concerning the chemical structure, tannins can be divided into four major groups: proanthocyanidins or condensed tannins (CT), hydrolysable tannins (HT), phlorotannins which are found in marine brown algae, and complex tannins (Serrano, 2009). Hydrolysable tannins and CT, also known as proanthocyanidins, are the two major groups of these bioactive compounds. The HT are complex molecules with a carbohydrate as a central core, such as glucose, glucitol, quinic acids, quercitol or shikimic acid. This central core is esterified with a phenolic group like gallic acid (3,4,5-trihydroxy benzoic acid; gallotannins) or gallic acid dimer hexahydroxydiphenic acid (ellagitannins) (Patra and Saxena, 2010). Condensed tannins are oligomers or polymers of flavanol units (flavan-3ols) commonly linked by carbon-carbon bonds in the $4 / 6$ or $4 / 8$ position. The structure of the $\mathrm{CT}$ varies depending on the number and positions of the hydroxyl groups, the type and position of linkage between successive monomeric units, and the degree of polymerization. Hydrolysable tannins are more soluble in water, and have a lower molecular weight than CT (Serrano, 2009; Jerónimo et al., 2016). Chemical composition of tannins, as well as their concentration, depends on plant species, the part of the plant, and environmental factors such as climate, soil, topography (Patra and Saxena, 2011), and phenological stage (Berard et al., 2011).

There are reports that both HT and CT may occur in the same plant (Waghorn, 2008), but some plants may contain predominantly HT whereas others contain CT. Hydrolysable tannins are found only in dicotyledonous plants, while CT can be found both in angiosperms and gymnosperms (Silanikove et al., 2001).

\section{EFFECTS OF TANNINS ON RUMINANTS DIGESTION}

In recent years tannins were used in intense nutritional studies. Research results indicate on diverse tannin effects on biological systems. Biological properties depend on their chemical structure (Makkar, 2003; Patra and Saxena, 2010), which can be even more important than concentration (Waghorn and McNabb, 2003). This is because of enormous structural variation among individual tannins. Lower molecular weight tannins have greater reactivity with proteins (Patra and Saxena, 2011). Furthermore, tannins can interact with other plants secondary compounds, such as saponins (Makkar, 2003). These facts led to a considerable confusion in the literature and consequently has not been sufficiently 
appreciated in many feeding trials (Lamy et al., 2011; Okuda and Ito, 2011).

For a long time, tannins were considered as antinutritive compounds due to their negative effect on intake, digestion and palatability of proteins, polysaccharides and minerals. Frequent use of tannin was also found to be toxic because of damaging kidney and liver, tissue in the rumen, and morphological changes at the microvilli level (Kumar and Singh, 1984; Silanikove et al., 1996; Crozier et al., 2009). Negative effect on body tissue was reported mostly for the HT, which are enzymatically depolymerised in the rumen to gallic acid, that is further metabolized by microbes to pyrogallol and other low molecular weight phenols, which are absorbed and responsible for cellular damage (Murdiati et al., 1992). Condensed tannins are not degraded and absorbed into the bloodstream, and are therefore not likely to damage organs. Their adverse effects are associated with lower voluntary intake and decreasing digestibility of proteins and carbohydrates.

Studies that compare different classes of tannins (HT versus CT) cannot be found in abundance and there is still perception that HT are toxic in comparison with CT. In contrast, many articles have reported HT beneficial role in nutrition, as demonstrated by higher live weight gains or milk yields (Stewart et al., 2000). The consumption of small quantities of HT in soya bean meal $\left(20.8 \mathrm{~g} \mathrm{~kg}^{-1}\right.$ dry matter (DM) by Merino sheep under practical finishing conditions, showed that these compounds were neither toxic nor had any negative effect on animal performance (Frutos et al., 2004).

\section{Digestion of proteins}

Most of the previous research, especially research on tannins in forages and tree leaves, are focused on protection of proteins, which is one of the most important nutritive characteristics of tannins. The basic goal of protein nutrition balance in ruminants is to optimize dietary protein use in order to maximize animal growth and milk production per unit of protein consumed. In ruminants, nutrient are subjected first to fermentative digestion by rumen microorganisms. Eventually products of the microbial fermentation become available as energy (volatile fatty acids) and protein (microbial cells) for animal tissue metabolism (Bunglavan, 2013).

When ruminants are fed with forages containing high concentration of proteins, the proteins in feed become rapidly soluble. In the rumen proteins are degraded by rumen microorganisms to high levels of ammonia. High level of ammonia is absorbed from the rumen and excreted in urine (Ulyatt et al., 1975). Some, but not all, tannins can reduce the amount of protein that is digested in the rumen and enhance the amount of protein that is available for digestion in the small intestine (Frutos et al., 2004; Mueller-Harvey, 2006). Complexes are formed between proteins and tannins. This is due to presence of high number of phenolic groups where bonding may occur with the carbonyl groups of peptides (Bunglavan and Dutta, 2013). Complexes are stable from microbial hydrolysis and deamination in the rumen. Stable complexes are increasing total number of dietary amino acids available for post ruminal absorption. Tannin-protein complexes are then available in abomasum and digested in intestine (Bunglavan and Dutta, 2013). Still, McNeill et al. (1999) indicated that tannins released in abomasum react with non-dietary protein (including digestive enzymes) in intestines, which can offset the positive effects of tanninprotein bond (McNeill et al., 1999).

Protein tannin complexes are influenced by concentration of both, molecular weight of tannins, protein structure (size, conformation, and amino acid composition), and nature of the medium in which the interactions take place (solvent, temperature, $\mathrm{pH}$ ) (Le Bourvellec and Renarda, 2012). Their main effect on proteinsisbased on their ability to form hydrogen bonds that are stable between $\mathrm{pH} 3.5$ and 8 (approximately) (Jerónimo et al., 2016). Jones and Mangan (1977) carried in vitro and in vivo study to determine the nature of complexes formed between proteins and tannins in sainfoin (Onobrychis viciifolia). Protein complexes were stable in vitro between $\mathrm{pH}$ 3.5 and $\mathrm{pH} 7.0$ (rumen $\mathrm{pH}$ ranges between 5.7 and 7.3). Then by shifting $\mathrm{pH}$, complexes dissociated (in the abomasum $\mathrm{pH}$ is <3.5). In vivo trial of the same study, experiments with sheep fed with sainfoin, confirmed the in vitro results. The tannin protein complexes were stable in rumen $(\mathrm{pH} 6.5)$ and break-up in in the duodenum (Jones and Mangan, 1977). This led to the hypothesis that tannin-protein complexes are formed in the rumen and then dissociate when the $\mathrm{pH}$ falls below 3.5 (in the abomasum, $\mathrm{pH} 2.5-3$ ) or is greater than 8 (in the duodenum, $\mathrm{pH} 8$ ), thus making it available for gastric or pancreatic digestion (Mueller-Harvey, 2006). Makkar and Becker (1996) also reported that quebracho tannins increased the rate of inactivation at $\mathrm{pH} 11$. The results suggested that alkaline $\mathrm{pH}$ inactivates the tannins (Makkar and Becker, 1996). The decreased rate and extent of protein degradation in the rumen, as observed due to feeding of tannin-rich feeds, could lower ammonia concentrations in the rumen and hence urea $\mathrm{N}$ excretion in urine (West, 1993).

Both types of tannin (CT and HT) complex with protein by forming hydrogen bond (McSweeney et al., 2001). Many in vitro and in vivo studies have confirmed reduction in degradation of proteins by the presence of CT in the diet (Min et al., 2003; Theodoridou et al., 2010; Dentinho et al., 2014). Waghorn et al. (1994) reported that the principal effects of CT were to increase the flow of feed nitrogen $(\mathrm{N})$ to the abomasum despite a $12 \%$ reduction in DM intake of the sheep fed with tannins. Ngwa et al. (2002) fed Acacia sieberiana pods (containing CT) to the sheep. The pod and silage diets increased fecal $\mathrm{N}$ and lowered urinary $\mathrm{N}$ excretion by sheep. Kariuki (2004) studied effect of different Leucaena species containing CT in the diet of sheep. Supplementation of CT improved the release of previously bound feed protein post ruminally, in the intestine. Hervás et al. (2000) studied the effect of tannic acid, a HT, on ruminal degradation and post ruminal digestion of treated soya bean meals (SBM) in sheep. Samples of SBM were prepared by spraying $100 \mathrm{~g} \mathrm{SBM}$ with $100 \mathrm{ml}$ distilled water containing $0,1,5,10,15$ or $25 \mathrm{~g}$ of commercial tannic acid. Results showed significant reduction in the extent of crude protein degradation in the rumen. The effect was significant even at the lowest dose. With respect to the intestinal digestibility of the non degraded protein, no negative effects were detected until the $15 \mathrm{~g}$ dose was reached. The reduction in rumen protein degradation leads to lower 
level of $\mathrm{N}-\mathrm{NH} 3$ production in the rumen. As a result, the urinary $\mathrm{N}$ is reduced and the fecal $\mathrm{N}$ slightly increases. This is result of not degraded tannin protein complexes formed along the digestive tract (Mueller-Harvey, 2006).

The reduction of protein degradation in the rumen can also been affected by inhibition of the growth and activitiy of proteolytic bacterial populations (Patra and Saxena, 2011). In the biggest extend four different species of bacteria influences a proteolytic activity (Ruminobacter amylophilus, Prevotella ruminicola, Streptococcus bovis and Butyrivibrio fibrisolvens) although, other species also influence proteolysis (McMahon, 2000). In the in vitro study of Jones et al. (1994) effect of on different sainfoin CT on different species of bacteria was studied. Sainfoin leaf CT inhibited growth and protease activity in Butyrivibrio fibrisolvens and Streptococcus bovis. On the other hand there were little effect on Prevotella ruminicola and Ruminobacter amylophilus. Tannins bound to cell coat polymers in all strains. Morphological changes in $B$. fibrisolvens and S. bovis implicated the cell wall as a target of tannin toxicity (Jones et al., 1994).

It remains to be determined whether reduced protein utilization associated with tannins is a result of protein protection, or a direct inhibition of proteolytic bacteria (McMahon, 2000).

\section{Digestion of carbohydrates}

In the literature, not much data is available in association with the effects of tannins on carbohydrates.

High concentrations of CT in Lotus pedunculatus reduced rumen digestion of carbohydrate and hemicellulose, but this was counteracted by increased post-ruminal digestion (Barry and Manley, 1984). Waghorn et al. (1987) reported that carbohydrate digestion in sheep fed on L. corniculatus was not affected by CT. Sivka and Lavrencic (2007a) studied four different concentrations (0 (control), 0.33, 0.67 and $1.33 \mathrm{mg} \mathrm{ml}^{-1}$ medium) of three tannin extracts (chestnut, quebracho extracts and tannic acid) used to investigate their effect on the kinetics of in vitro fermentation of starch. In vitro gas production method was measured at $0,2,4,6,8$, $10,12,24,36,48,72$ and $96 \mathrm{~h}$ after the start of incubation. Rumen liquor was taken from two fistulated adult male sheep. Results show that compared to control, chestnut tannin and quebracho tannin decreased total potential gas production of starch. On contrary, tannic acid increased the total potential gas production of starch by $6 \%$. The maximum fermentation rate of starch occurred after almost 9 hours. These results suggest that tannin extracts with their ability to bind to microorganisms, their enzymes and substrate alter the kinetics of in vitro starch fermentation (Sivka and Lavrencic, 2007a). Sivka and Lavrencic (2007b) concluded that HT modified the kinetic parameters of in vitro cellulose fermentation by increasing time of maximum fermentation rate of cellulose, and significantly decreased maximum fermentation rate of cellulose. This is presumably due to forming unfermentable complexes of tannins with substrate (cellulose) and by decreasing the activity of microorganisms and/or microbial enzymes (Sivka and Lavrencic, 2007b). However, when Terminalia chebula was fed to sheep at $10 \mathrm{~g} \mathrm{~kg}^{-1}$ of total DM intake, the digestibility of nutrients and fiber fractions increased (Patra and Saxena, 2009). This could be attributed to the increased numbers of fibrolytic bacterial populations in the rumen (Patra and Saxena, 2010).

Rate and extent of starch digestion in the rumen are affected by different factors, including source of dietary starch, diet composition, amount of feed consumed, mechanical and chemical alterations and degree of adaptation of rumen microbiota to the diet (Sivka in Lavrencic, 2007a, b). Condensed tannins and HT are capable to form complexes carbohydrates (Makkar, 2003). McSweeney et al. (2001) reported that tannins form hydrogen bonds with cellulose, hemicelluloses, starch and pectin. Tannins reduce fibre digestion by inhibition of bacterial enzymes involved in the carbohydrate metabolism (cellulases, amylases and galactosidases) or by substrate deprivation (binding with lignocellulose, cellulose, hemicelluloses, starch and pectin) or both (McSweeney et al., 2001).

Patra and Saxena (2010) concludes, that higher concentrations of tannins in diets, which remain free after binding with proteins, may depress fibre digestion by forming complexes with lignocellulose and thus preventing microbial digestion, or by directly inhibition of cellulolytic microorganisms and activities of fibrolytic enzymes or both. Although the nature of binding with carbohydrates has not been determined, it is stated that this binding is relatively independent of $\mathrm{pH}$ and is influenced by the type of tannins (molecular weight, flexibility and water solubility) included in the diets.

\section{EFFECTS OF TANNINS ON RUMINANT PERFORMANCE}

Most of the previous research on feed intake involved different forages containing different tannins which lead to contradictory reports about their benefits. The impact on performance may include the improved growth, higher milk yields, higher tolerance to some intestinal parasites and bloat prevention.

\section{Voluntary intake}

In earlier publications (e.g., Barry and Manley, 1984; Waghorn et al., 1994) we can find reports that the consumption of tannins negatively affect voluntary feed intake. It has generally been advised that tannin concentrations greater than $50 \mathrm{~g} \mathrm{~kg}^{-1}$ in diets may negatively affect feed intake. The study conducted by Barry and Duncan (1984), reported that high concentration of CT in Lotus pedunculatus affected the voluntary feed intake (VFI) in sheep. Diet containing 62 and $106 \mathrm{~g} \mathrm{~kg}^{-1} \mathrm{DM}$ reduced VFI for more than $27 \%$. Hervas et al. (2003) included in their study four groups with different dosage of quebracho tannins in the diet of sheep: Q $0\left(0 \mathrm{~g} \mathrm{~kg}^{-1}\right.$ tannin), Q1 (0.5 $\left.\mathrm{g} \mathrm{kg}^{-1}\right)$, Q2 $\left(1.5 \mathrm{~g} \mathrm{~kg}^{-1}\right)$ and Q3 $\left(3.0 \mathrm{~g} \mathrm{~kg}^{-1}\right)$ (equal to $0,28,83$ and $166 \mathrm{~g} \mathrm{~kg}^{-1} \mathrm{DM}$ ). Animals in groups Q0, Q1and Q2 consumed all the offered feed during whole time of experiment. In contrast, feed intake was practically 
zero after 6 days of quebracho dosing in group Q3. The same study also reported that sheep from groups Q0, Q1 and Q2 remained healthy throughout the experiment. Group Q3 became weak and depressed on day 5 and after 8 days of dosing remained recumbent. They were humanely killed after 10 days to avoid suffering. Here we can conclude that dosage of tannins directly affect voluntary intake by sheep. Smaller depressions in VFI (-12\%) were caused by 55 g CT $\mathrm{kg}^{-1} \mathrm{DM}$ in Lotus pedunculatus (Waghorn et al., 1994). It was also noticed that medium values of CT concentrations (34 and $44 \mathrm{~g} \mathrm{~kg}^{-1} \mathrm{DM}$ ) had no effect upon VFI (Wang et al., 1996) in sheep.

The same was reported for HT. The VFI was mostly dependent on quantity of HT consumed by animals. The study of Frutos et al. (2004) included lambs and diet with HT. A small amount of a chestnut HT extract included in the diet $\left(20.8 \mathrm{~g} \mathrm{~kg}^{-1} \mathrm{DM}\right)$ of finishing lambs as a feed additive did not cause toxic effects and did not negatively affect lamb performance. However, in an experiment with sheep fed by $8.0 \mathrm{~g}$ of tannic acid per kg liveweight, VFI dropped drastically after $24 \mathrm{~h}$ (from 18.0 to $21.5 \mathrm{~g} \mathrm{DM} \mathrm{kg}^{-1} \mathrm{LW}$ ) (Zhu et al., 1992).

As stated above, the low intake of feeds rich in tannins is attributed to a low palatability because of the sensation of astringency that tannins confer on feed by binding with salivary proteins (Lesschaeve and Noble, 2005). Three main mechanisms have been suggested to explain the negative effects of high tannin concentrations on VFI: a reduction in feed palatability, the slowing of digestion, and the development of aversions (Frutos et al., 2004). A reduction in palatability could be caused through a reaction between the tannins and the salivary mucoproteins, or through a direct reaction with the taste receptors, provoking an astringent sensation (McLeod, 1974). Ruminants secrete these prolinerich proteins constantly, while sheep, for example, only produce them when consuming plants rich in tannins (Austin et al., 1989). In cattle, the production of such proteins has not been observed in response to tannin ingestion, although other proteins with high affinity for these polyphenols has been found in their saliva (Makkar and Becker, 1998, Addisu, 2016).

\section{Effects on production}

Waghorn (2008) studied productive response to forages containing CT. This study revealed positive effect of CT, by increasing daily gain from 8 to $38 \%$, and from 10 to 21 $\%$ for milk production compared to controls. These effects were also confirmed by other researchers. Wang et al. (1996) compared effect of CT upon the performance of lambs grazing bird's-foot trefoil (Lotus corniculatus - contained $34 \mathrm{~g}$ total CT $\mathrm{kg}^{-1} \mathrm{DM}$ ) and alfalfa (Medicago sativa - no tannins detected). Compared to lambs grazing alfalfa, lambs grazing L. corniculatus had slightly lower VFI, but higher live weight gain (LWG), carcass weight gain, carcass dressingout percentage and wool growth. Montossi et al. (1997) published similar results. These authors observed a $23 \%$ improvement in LWG when lambs grazed Holcus lanatus (4.2 $\left.\mathrm{g} \mathrm{CT} \mathrm{kg}^{-1} \mathrm{DM}\right)$. Min et al. (2006) fed steers with $2 \%$
CT from quebracho and obtained an increase of $20.8 \%$ in LWG; similarly Ayala-Monter (2013) reported that when they added $2.5 \%$ CT in ration, daily weight gain (DWG) increased by $5.5 \%$. However, Lotus pedunculatus containing 76-90 $\mathrm{g} \mathrm{CT} \mathrm{kg}^{-1}$ of DM decreased rates of body weight gain and wool growth (Barry, 1985) which was explained by the presence of high concentrations or different types of CT in forages. Beauchemin et al. (2007) studied the effect of tannin extract from quebracho trees to Angus heifers and steers. Study showed that feeding by quebracho tannin extract had no effect on body weight, average daily gain (ADG), or nutrient intakes. Furthermore, it had no effect on DM, energy, or fiber (Acid Detergent Fiber and Neutral Detergent Fiber) digestibility.

Mezzomo at al. (2017) studied effects of replacement of soybean meal with soybean meal treated with tannin mixture (85\% CT and $15 \%$ HT) on the intake, digestibility, performance and characteristics of the carcasses of young cattle fed a high-concentrate diet. There was a linear decline in DM intake when soybean meal was replaced with soybean meal treated with tannin. No decrease in carcass weight was observed. Still, there were changes in carcass gain composition with an increase in muscle and reduction in fat deposition. The use of tannins causes changes in body gain composition in animals and reduces DM intake by the animals, achieving a better feed conversion efficiency (Mezzomo et al., 2017).

Frutos et al. (2004) demonstrated no effect of chestnut tannin (HT) on lamb carcass traits when fed a high-grain diet supplemented with approximately $0.84 \mathrm{~g}$ tannin $\mathrm{kg}^{-1}$ body weight (BW); there was no effect of HT supplementation on ADG, feed efficiency, and length of finishing period. Although these tannins can be readily degraded by rumen microbiota, they can affect ruminal fermentation as CT do (Frutos et al., 2004, Brus et al., 2017). In respect to HT, in a different experiment, Tabacco et al. (2006) conducted experiments with alfalfa in order to investigate the effects of the addition of commercial chestnut HT at ensiling on silage fermentation quality in lab-scale silos and protein degradation in the rumen, and silage fermentation quality and proteolysis in bale silages. The results showed that low levels of chestnut HT, reduced crude protein ruminal disappearance by reducing proteolysis in silages and positively affected the silage quality by improve protein utilization.

The effect of HT on ruminal fermentation is caused by the reduction in the attachment of microbes to feed particles (McAllister et al., 1994) and an inhibition of the growth of micro-organisms and the activity of microbial enzymes (Doce et al., 2011; McSweeney et al., 2001). Doce et al. (2011) used oak leaves to feed young bulls (HT). The results of the experiment showed that the daily administration of up to $5 \mathrm{~kg}$ neither appreciably affected ruminal fermentation nor caused toxicity to the animals. However, administration of $10 \mathrm{~kg}$ of fresh oak leaves per animal and day preceded by a severe feed restricting period and triggered a critical reduction in rumen fermentation activity concomitantly with an acute intoxication. According to these results, the presence of tannins (mainly HT) in the rumen of animals on treatments with lower dosage would have elicited changes in their microbial populations or favored the development of microbial mechanisms of adaptation, whereas the highest 
level would have exceeded their ability to tolerate or detoxify tannins, in agreement with the intoxication signs observed in animals treatment (Doce et al., 2011). Lowry et al. (1996) reported that ruminants eating diets containing HT reduce their urinary excretation of degradation products as they became accustomed to the toxins. Brus et al. (2017) studied HT effect on Simmental bulls. Results from twelve-month feeding trial revealed that ADG in the first 7 months of the feeding trial was numerically higher in the control group (no tannins). After the 8th month of investigation the group supplemented with tannins showed significantly higher ADG than the control group. Authors also reported that tannin feed supplement help animals better tolerate nutritional and metabolic imbalances and results in smaller production losses for the farmers (Brus et al., 2017).

Increase in milk production has been recorded in several experiments. Wang et al. (1996) studied the effect of $L$. corniculatus fed to lactating ewes. Study revealed increased milk yield (21\%), lactose (12\%) and protein (14\%) in milk respectively, during mid and late lactation. Lactating dairy cows fed diets containing 8-6\% peanut skins (180 g CT $\mathrm{kg}^{-1}$ ) resulted in higher DM intakes, milk yield and milk fat content but had lower milk protein content (West et al., 1993). Ali et al. (2017) showed that the milk production was found significantly higher when dairy crossbred cows were fed with supplement of $40 \mathrm{~g}$ HT per day. They also noticed that the milk protein and lactose (\%) were increased with supplementation of HT. Dubey (2007) reported significant increase in milk yield from 9.44 to $10.35 \mathrm{~kg} /$ day/cow by adding $3 \%$ tannin from Acacia nilotica pods in crossbred cows. Kushwaha et al. (2012) reported no effect of CT in ewes grazing Lotus corniculatus in early lactation, but there was an increase in milk yield by 2 liters during mid and late lactation. Woodward et al. (2000) conducted study on Friesian dairy cows feed on Lotus corniculatus. Increase in milk yield was considerable higher ( $46 \%$ ) when cows were fed with lotus instead ryegrass. Tannins had no effect on intake but contributed to increased milk protein concentration, increased efficiency and decreased milk fat concentration. Anantasook et al. (2014) noticed an increase of $10 \%$ in milk yield of cows fed $88 \mathrm{~g}$ CT per kg DM. Dey et al. (2014) with crossbred cows fed $1.5 \%$ CT per kg DM were able to increase milk yield by $24.7 \%$ compared to cows without CT in ration.

On the other hand Grainger et al. (2009) noted a decrease of $29.7 \%$ in milk production when cows were fed with 244 $\mathrm{g}$ of tannins (CT) per day. This reduction was related to a decrease to $26.4 \%$ in feed intake induced by CT. Moreover, Beaucheminet al. (2007) did not note any significant effect on growth and intakes when cattle were fed with forage-based diet supplemented with quebracho tannins. No change in milk production and milk composition were observed by addition of CT reported by Benchaar et al. (2008). In the study of Colombini et al. (2010), milk yield was also not affected by offering silage treated with tannin.

Ali et al. (2017) studied the effect of HT on production performance (milk production and composition) of dairy crossbred cows. The cows were randomly divided into four groups: without supplementation, and with 20, 30 and 40 g HT per day, respectively. Results showed that the milk production was found significantly higher in group with highest tannin additive. The differences in milk fat and total solids were non-significant, however, the milk protein and lactose were increased with supplementation of HT. Reduction in milk urea content of animals was also detected by cows fed with HT. The supplementation of HT also results in the reduction of somatic cell count (Ali et al., 2017).

We noted that many author reported significant increases in the efficiency of milk production, increased protein and lactose production, and a decrease in the fat content of the milk. Increased concentration of protein might be explained by the greater availability of intestinal amino acids, which are thought to limit milk production. The greater concentration of lactose can be explained by greater glucose supply; most lactose synthesis in the mammary gland relies directly on blood glucose, and in ruminants gluconeogenesis mainly involves propionic acid and amino acids. The reduction in the concentration of fat was attributed to a simple dilution effect as the concentrations of lactose and protein increased (Frutos et al., 2004).

\section{Bloat prevention and effect on health}

Probably the most successful application of tannins in ruminant production is to reduce frothy bloat. Bloat can occur during feeding of legumes which are high in easily degradable proteins such as young lucerne or different varieties of clover. Gas produced during fermentation of feeds is trapped within the rumen in the form of a stable foam. This foam prevents normal expulsion of these gases and, as a consequence, ruminal volume and intraruminal pressure increase (McMahon et al., 2000).

McMahon et al. (1999) studied the effects of sainfoin (Onobrychis viciifolia) on digestion of alfalfa (Medicago sativa). Sainfoin tannins reduced degradation of forage protein without affecting the digestibility of the nonprotein fraction. Including sainfoin in the diet reduced the incidence of bloat by 45 to $93 \%$. Li et al. (1996) mentioned that a minimum concentration of $50 \mathrm{~g} \mathrm{CT} \mathrm{kg}^{-1}$ in forages is needed to consider forages bloat-safe. Tannins reduce the soluble protein concentration in the rumen, thereby limiting production of the stable foam known to be associated with bloat (Majak et al., 1995; McMahon et al., 1999).

\section{Effect on internal parasites}

Alternative parasitic control strategies have been studied, and the use of tannin-rich feeds has been one of the proposed alternatives (Niezen et al., 1995; Nguyen et al., 2005). Tannin-rich plants have attracted most attention for their effect on internal nematodes in ruminants. External tannins such as those from mimosa (HT), chestnut (HT) and quebracho (CT) have been used to control various intestinal parasites in ruminant (Butter et al., 2001; Min and Hart, 2003). Hoste et al. (2006) summarized findings of in vivo studies and concluded that tannins from sainfoin, sulla, Lotus pedunculatus, Sericea lespedeza, Acacia nilotica and chicory had significant anthelmintic effects in digestive tract of sheep, goat and deer. Moreover, the CTs extracted 
from Lotus pedunculatus, Lotus corniculatus, Hedychium coronarium and Onobrychis viciifolia had anthelmintic-like activity against deer lungworm and gastrointestinal larvae, suggesting that these forages could be used as an alternative approach in controlling internal parasites in deer (Molan et al., 2000). Niezen et al. (2002) investigated the efficacy of the legume Hedysarum coronarium (sulla), which contains CT, for reducing gastrointestinal nematode infections relative to lucerne. Animals grazing sulla had much lower number of gastrointestinal parasites and had better ADG. The results of this study suggest that CT may be able to break the life cycle of nematodes and thus reduce the contamination of pastures with viable eggs.

\section{CONCLUSION}

As it was mentioned in the text, tannin supplementation in ruminant nutrition in appropriate concentration never had caused negative effects on animal performance. The majority of studies reveal that tannin supplementation offeres benefits for the beef industry. This was proven in many in vitro and especially in vivo trails. Some experiments showed that concentrations in feeding trial were not too accurate, mostly too low, and consequently no differences were detected within experiments. This is true either for HT or CT supplementation. In addition, most studies focussed on forages (mostly legumes) and tree leaves tannin supplementation. Not much is known about tannins extracts, especially on HT like extract from chestnut or oak. It would be advisable to investigate the effects of these extracts in dairy cattle or in fattening steers or bulls. Although substantial benefits of tannins for ruminant productivity and quality have been reported, there is a need to investigate their effectiveness in larger feeding trials, where source and appropriate dosages of tannins can be more accurately determined.

\section{REFERENCES}

1. Addisu, S. (2016). Effect of dietary tannin source feeds on ruminal fermentation and production of cattle; a review. Online Journal of Animal and Feed Research, 6, 45-56.

2. Ali, M., Mehboob, H. A., Mirza, M. A., Raza, H., \& Osredkar, M. (2017). Effect of hydrolysable tannin supplementation on production performance of dairy crossbred cows. The Journal of Animal \& Plant Sciences, 27(4), 1088-1093.

3. Anantasook, N., Wanapat, M., \& Cherdthong, A. (2014). Manipulation of ruminal fermentation and methane production by supplementation of rain tree pod meal containing tannins and saponins in growing dairy steers. Journal of Animal Physiology and Animal Nutrition, 98(1), 50-55.

4. Austin, P. J., Suchar, L. A., Robbins, C. T., \& Hagerman, A. E. (1989). Tannin-binding proteins in saliva of deer and their absence in saliva of sheep and cattle. Journal of
Chemical Ecology, 15(4), 1335-1347.

5. Ayala Monter, M. A. (2013). Inclusión de taninos en la dieta de ovinos en finalización: respuesta en calidad de la carne. Tesis de Maestría en Ciencias de los Recursos Genéticos y Productividad. Colegio de Postgraduados, Texcoco, Estado de México, México.

6. Barry, T. N., \& Duncan, S. J. (1984). The role of condensed tannins in the nutritional value of Lotus pedunculatus for sheep: 1. Voluntary intake. British Journal of Nutrition, 51(3), 485-491.

7. Barry, T. N., \& Manley, T. R. (1984). The role of condensed tannins in the nutritional value of Lotus pedunculatus for sheep: 2. Quantitative digestion of carbohydrates and proteins. British Journal of Nutrition, 51(3), 493-504.

8. Barry, T. N. (1985). The role of condensed tannins in the nutritional value of Lotus pedunculatus for sheep: 3 . Rates of body and wool growth. British Journal of Nutrition, 54(1), 211-217.

9. Barry, T. N., \& McNabb, W. C. (1999). The implications of condensed tannins on the nutritive value of temperate forages fed to ruminants. British Journal of Nutrition, 81(4), 263-272.

10. Beauchemin, K. A., McGinn, S. M., Martinez, T. F., \& McAllister, T. A. (2007). Use of condensed tannin extract from quebracho trees to reduce methane emissions from cattle. Journal of Animal Science, 85(8), 1990-1996.

11. Benchaar, C., McAllister, T. A., \& Chouinard, P. Y. (2008). Digestion, ruminal fermentation, ciliate protozoal populations, and milk production from dairy cows fed cinnamaldehyde, quebracho condensed tannin, or Yucca schidigera saponin extracts. Journal of. Dairy Science, 91(12), 4765-4777.

12. Berard, N. C., Wang, Y., Wittenberg, K. M., Krause, D. O., Coulman, B. E., McAllister, T. A., \& Ominski, K. H. (2011). Condensed tannin concentrations found in vegetative and mature forage legumes grown in western Canada. Canadian Journal of Plant Science, 91(4), 669675.

13. Brus, M., Mergeduš, A., Prevolnik Povše, M., \& Janžekovič, M. (2017). Better tolerance against dietary mycotoxins in fattening bulls when supplemented with Farmatan-D. Agriculturae Conspectus Scientificus, 82(3), 303-306.

14. Bunglavan, S. J., \& Dutta, N. (2013). Use of tannins as organic protectants of proteins in digestion of ruminants. Livestock Science, 4, 67-77.

15. Butter, N. L., Dawson, J. M., Wakelin, D., \& Buttery, P. J. (2001). Effect of dietary condensed tannins on gastrointestinal nematodes. Journal of Agricultural Science, 137(4), 461-469.

16. Cobellis, G., Yu, Z., Forte, C., Acuti, G., \& Trabalza-Marinucci, M. (2016). Dietary supplementation of Rosmarinus officinalis L. leaves in sheep affects the abundance of rumen methanogens and other microbial populations. Journal of Animal Science and Biotechnology, 7(1), 27.

17. Colombini, S., Rapetti, L., Colombo, D., Galassi, G., \& Crovetto, G. M. (2010). Brown midrib forage sorghum silage for the dairy cow: nutritive value and comparison 
with corn silage in the diet. Italian Journal of Animal Science, 9(3), e53.

18. Crozier, A., Jaganath, I. B., \& Clifford, M. N. (2009). Dietary phenolics: chemistry, bioavailability and effects on health. Natural Product Reports, 26(8), 1001-1043.

19. Dentinho, M. T. P., Belo, A. T., \& Bessa, R. J. B. (2014). Digestion, ruminal fermentation and microbial nitrogen supply in sheep fed soybean meal treated with Cistus ladanifer L. tannins. Small Ruminant Research, 119(1), 57-64.

20. Dey, A., \& De, P. S. (2014). Influence of condensed tannins from Ficus bengalensis leaves on feed utilization, milk production and antioxidant status of crossbred cows. Asian-Australasian Journal of Animal Science, 27(3), 342.

21. Doce, R. R., Hervas, G., Giraldez, F. J., López-Campos, O., Mantecón, A. R., \& Frutos, P. (2007). Effect of immature oak (Quercus pyrenaica) leaves intake on ruminal fermentation and adaptation of rumen microorganisms in cattle. Journal of Animal and Feed Science, 16(2), 1318.

22. Dixon, R. A., Xie, D. Y., \& Sharma, S. B. (2005). Proanthocyanidins - a final frontier in flavonoid research? New Phytologist, 165(1), 9-28.

23. Fitzhugh, H. A., Hodgson, H. J., Scoville, O. J., Nguyen, T. D., \& Byerly, T. C. (1978). The role of ruminants in support of man. Winrock International Livestock Research and Training Centre, Morrilton, USA.

24. Frutos, P., Raso, M., Hervás, G., Mantecón, Á. R., Pérez, V., \& Giráldez, F. J. (2004). Is there any detrimental effect when a chestnut hydrolysable tannin extract is included in the diet of finishing lambs? Animal Research, 53(2), 127-136.

25. Grainger, C., Clarke, T., Auldist, M. J., Beauchemin, K. A., McGinn, S. M., Waghorn, G. C., \& Eckard, R. J. (2009). Potential use of Acacia mearnsii condensed tannins to reduce methane emissions and nitrogen excretion from grazing dairy cows. Canadian Journal of Animal Science, 89(2), 241-251.

26. Hervás, G., Frutos, P., Serrano, E., Mantecón, A. R., \& Giráldez, F. J. (2000). Effect of tannic acid on rumen degradation and intestinal digestion of treated soya bean meals in sheep. Journal of Agricultural Science, 135(3), 305-310.

27. Hervás, G., Frutos, P., Giráldez, F. J., Mantecón, Á. R., \& Del Pino, M. C. Á. (2003). Effect of different doses of quebracho tannins extract on rumen fermentation in ewes. Animal Feed Science and Technology, 109(1), 65-78.

28. Hoste, H., Jackson, F., Athanasiadou, S., Thamsborg, S. M., Hoskin, S. O. (2006). The effects of tannin-rich plants on parasitic nematodes in ruminants. Trends in Parasitology, 22 (6), 253-261.

29. Jerónimo, E., Pinheiro, C., Lamy, E., Dentinho, M. T., Sales-Baptista, E., Lopes, O. S., Capela e Silva, F. (2016). Tannins in ruminant nutrition: Impact on animal performance and quality of edible products. In Combs, C. A. (Ed.), Tannins: Biochemistry, Food Sources and Nutritional Properties. New York, USA: Nova Science Publishers Inc.

30. Jones, W. T., \& Mangan, J. L. (1977). Complexes of the condensed tannins of sainfoin (Onobrychis viciifolia Scop.) with fraction 1 leaf protein and with submaxillary mucoprotein, and their reversal by polyethylene glycol and $\mathrm{pH}$. Journal of the Science of Food Agriculture, 28(2), 126-136.

31. Jones, G. A., McAllister, T. A., Muir, A. D., \& Cheng, K. J. (1994). Effects of sainfoin (Onobrychis viciifolia Scop.) condensed tannins on growth and proteolysis by four strains of ruminal bacteria. Applied Environmental Microbiology, 60(4), 1374-1378.

32. Kariuki, I. (2004). The digestion of condensed tanninbound dietary protein in the gastro-intestinal tract of sheep. Condensed tannins in tropical legume fodder trees: characterisation, and interaction with rumen microbes, feed, and endogenous protein, $\mathrm{Ph}$. D. Thesis, University of Queensland, Australia.

33. Krueger, W. K. (2009). Understanding beef cattle efficiency: (I) Understanding physiological and digestive factors affecting residual feed intake and (II) tannin supplementation: effects on animal performance, fermentation, and carcass traits. Texas A\&M University.

34. Kumar, R., \& Singh, M. (1984). Tannins: their adverse role in ruminant nutrition. Journal of Agricultural and Food Chemistry, 32(3), 447-453.

35. Kushwaha, R., Rai, S. N., \& Singh, A. K. (2012). Effect of feeding Acacia nilotica pods on body weight, milk yield and milk composition in lactating goats. Indian Journal of Animal Research, 46(4), 366-370.

36. Lamy, E., Rawel, H., Schweigert, F. J., Capela e Silva, F., Ferreira, A., Costa, A. R., Antunes C. M., Almeida A. M., Coelho A. V., \& Sales-Baptista, E. (2011). The effect of tannins on Mediterranean ruminant ingestive behavior: the role of the oral cavity. Molecules, 16(4), 2766-2784.

37. Lesschaeve, I., \& Noble, A. C. (2005). Polyphenols: factors influencing their sensory properties and their effects on food and beverage preferences. American Journal of Clinical Nutrition, 81(1), 330S-335S.

38. Le Bourvellec, C., \& Renard, C. M. G. C. (2012). Interactions between polyphenols and macromolecules: quantification methods and mechanisms. Critical Reviews in Food Science and Nutrition, 52(3), 213-248.

39. Li, Y. G., Tanner, G., \& Larkin, P. (1996). The DMACA$\mathrm{HCl}$ protocol and the threshold proanthocyanidin content for bloat safety in forage legumes. Journal of the Science of Food Agriculture, 70(1), 89-101.

40. Lowry, J. B., McSweeney, C. S., \& Palmer, B. (1996). Changing perceptions of the effect of plant phenolics on nutrient supply in the ruminant. Australian Journal of Agricultural Research, 47(6), 829-842.

41. Majak, W., Hall, J. W., \& McCaughey, W. P. (1995). Pasture management strategies for reducing the risk of legume bloat in cattle. Journal of Animal Science, 73(5), 1493-1498.

42. Makkar, H. P. S., \& Becker, K. (1996). Effect of pH, temperature, and time on inactivation of tannins and possible implications in detannification studies. Journal of. Agricultural and Food Chemistry, 44(5), 1291-1295.

43. Makkar, H. P. S., \& Becker, K. (1998). Adaptation of catthe to tannins: role of proline-rich proteins in oak-fed cattle. Animal Science, 67(2), 277-281. 
44. Makkar, H. P. S. (2003). Effects and fate of tannins in ruminant animals, adaptation to tannins, and strategies to overcome detrimental effects of feeding tannin-rich feeds. Small Ruminant Research, 49(3), 241-256.

45. McAllister, T. A., Bae, H. D., Yanke, L. J., Cheng, K. J., \& Muir, A. (1994). Effect of condensed tannins from birdsfoot trefoil on endoglucanase activity and the digestion of cellulose filter paper by ruminal fungi. Canadian Journal of Microbiology, 40(4), 298-305.

46. McMahon, L. R., Majak, W., McAllister, T. A., Hall, J. W., Jones, G. A., Popp, J. D., \& Cheng, K. J. (1999). Effect of sainfoin on in vitro digestion of fresh alfalfa and bloat in steers. Canadian Journal of Animal Science, 79(2), 203212.

47. McMahon, L. R., McAllister, T. A., Berg, B. P., Majak, W., Acharya, S. N., Popp, J. D., \& Cheng, K. J. (2000). A review of the effects of forage condensed tannins on ruminal fermentation and bloat in grazing cattle. Canadian Journal of Plant Science, 80(3), 469-485.

48. McNeill, D. M., Osborne, N., Komolong, M., \& Nankervis, D. (1999). Condensed tannins in the Leucaena genus and their nutritional significance for ruminant. In: Shelton, H.M., Gutteridge, R.C., Mullin, B.F. \& Bray, R.A. (Eds.), Leucaena - Adaptation, quality and farming systems. ACIAR Proceedings no. 86: 205-214.

49. McSweeney, C. S., Palmer, B., McNeill, D. M., \& Krause, D. O. (2001). Microbial interactions with tannins: nutritional consequences for ruminants. Animal Feed Science and Technology, 91(1), 83-93.

50. Mezzomo, R., Paulino, P. V. R., Barbosa, M. M., Martins, T. S., Pereira, L. G. R., Silva, J. C., Paulino, M. F., Silva, M. C., \& Serão, N. V. (2017). Protein dietary efficiency and methane emission in cattle fed soybean meal treated with tannins. Animal Production Science, 58(12) 22332241.

51. Min, B. R., Barry, T. N., Attwood, G. T., \& McNabb, W. C. (2003). The effect of condensed tannins on the nutrition and health of ruminants fed fresh temperate forages: a review. Animal Feed Science and Technology, 106(1), 3-19.

52. Min, B. R., \& Hart, S. P. (2003). Tannins for suppression of internal parasites. Journal of Animal Science, 81, E102E109.

53. Min, B. R., Pinchak, W. E., Anderson, R. C., Fulford, J. D., \& Puchala, R. (2006). Effects of condensed tannins supplementation level on weight gain and in vitro and in vivo bloat precursors in steers grazing winter wheat. Journal of Animal Science, 84(9), 2546-2554.

54. Montossi, F., Hodgson, J., \& Morris, S. T. (1997). Herbage intake, ingestive behaviour and diet selection, and effects of condensed tannins upon body and wool growth in lambs grazing Lolium perenne and Holcus lanatus swards in summer. New Zealand Journal of Agricultural Research, 40(4), 449-461.

55. Mole, S., Rogler, J. C., \& Butler, L. G. (1993). Growth reduction by dietary tannins: different effects due to different tannins. Biochemical Systematics and Ecology, 21(6-7), 667-677.

56. Molan, A. L., Waghorn, G. C., Min, B. R., \& McNabb, W. C. (2000). The effect of condensed tannins from seven herbages on Trichostrongylus colubriformis larval migration in vitro. Folia Parasitologica, 47(1), 39-44.

57. Mueller-Harvey, I. (1999). Tannins: their nature and biological significance. In J. C. Caygill \& I. Mueller-Harvey (Eds.), Secondary plants products. Antinutritional and beneficial actions in animal feeding (pp: 17-70). UK: Nottingham University Press.

58. Mueller-Harvey, I. (2006). Unravelling the conundrum of tannins in animal nutrition and health. Journal of Science of Food Agriculture, 86(13), 2010-2037.

59. Murdiati, T. B., McSweeney, C. S., \& Lowry, J. B. (1992). Metabolism in sheep of gallic acid, tannic acid and hydrolysable tannin from Terminalia oblongata. Australian Journal of Agricultural Research, 43(6), 1307-1319.

60. Ngwa, A. T., Nsahlai, I. V., \& Iji, P. A. (2002). Effect of supplementing veld hay with a dry meal or silage from pods of Acacia sieberiana with or without wheat bran on voluntary intake, digestibility, excretion of purine derivatives, nitrogen utilization, and weight gain in South African Merino sheep. Livestock Production Science, 77(2), 253-264.

61. Niezen, J. H., Waghorn, T. S., Charleston, W. A. G., \& Waghorn, G. C. (1995). Growth and gastrointestinal nematode parasitism in lambs grazing either lucerne (Medicago sativa) or sulla (Hedysarum coronarium) which contains condensed tannins. Journal of Agricultural Science, 125(2), 281-289.

62. Niezen, J. H., Charleston, W. A. G., Robertson, H. A., Shelton, D., Waghorn, G. C., \& Green, R. (2002). The effect of feeding sulla (Hedysarum coronarium) or lucerne (Medicago sativa) on lamb parasite burdens and development of immunity to gastrointestinal nematodes. Veterinary Parasitology, 105(3), 229-245.

63. Nguyen, T. M., Van Binh, D., \& Ørskov, E. R. (2005). Effect of foliages containing condensed tannins and on gastrointestinal parasites. Animal Feed Science and Technology, 121(1), 77-87.

64. Okuda, T., \& Ito, H. (2011). Tannins of constant structure in medicinal and food plants-hydrolyzable tannins and polyphenols related to tannins. Molecules, 16(3), 2191-2217.

65. Ørskov, E. R. (1993). Reality in rural development aid: with emphasis on livestock. Aberdeen, UK: Rowett Research Services Ltd.

66. Osuji, P. O., Fernandez-Rivera, S., \& Odenyo, A. (1995). Improving fibre utilisation and protein supply in animals fed poor quality roughages: ILRI nutrition research and plans. In Workshop on Rumen Ecology Research Planning, Addis Ababa (Ethiopia), 13-18 Mar 1995. ILRI.

67. Patra, A. K., \& Saxena, J. (2009). Dietary phytochemicals as rumen modifiers: a review of the effects on microbial populations. Antonie van Leeuwenhoek, 96(4), 363-375.

68. Patra, A. K., \& Saxena, J. (2010). A new perspective on the use of plant secondary metabolites to inhibit methanogenesis in the rumen. Phytochemistry, 71(11), 11981222.

69. Patra, A. K., \& Saxena, J. (2011). Exploitation of dietary tannins to improve rumen metabolism and ruminant nutrition. Journal of the Science of Food and Agriculture, 91(1), 24-37. 
70. Piluzza, G., Sulas, L., \& Bullitta, S. (2014). Tannins in forage plants and their role in animal husbandry and environmental sustainability: a review. Grass and Forage Science, 69(1), 32-48.

71. Serrano, J., Puupponen-Pimiä, R., Dauer, A., Aura, A. M., \& Saura-Calixto, F. (2009). Tannins: current knowledge of food sources, intake, bioavailability and biological effects. Molecular Nutrition \& Food Reseach, 53(S2), S310-329.

72. Silanikove, N., Gilboa, N., Perevolotsky, A., \& Nitsan, Z. (1996). Goats fed tannin-containing leaves do not exhibit toxic syndromes. Small Ruminant Research, 21(3), 195-201.

73. Sivka, U., \& Lavrencic, L. (2007a). The course of fermentation of starch with the addition of different types of tannins. Acta Agriculturae Slovenica, 90(2), 85-95.

74. Sivka, U., \& Lavrenčič, A. (2007b). The effect of sweet chestnut extract (Farmatan $\left.{ }^{\circ}\right)$ on kinetics of in vitro cellulose fermentation. Krmiva, 49(3), 127-132.

75. Silanikove, N., Perevolotsky, A., \& Provenza, F. D. (2001). Use of tannin-binding chemicals to assay for tannins and their negative postingestive effects in ruminants. Animal Feed Science and Technology, 91(1), 69-81.

76. Stewart, J. L., Mould, F., \& Mueller-Harvey, I. (2000). The effect of drying treatment on the fodder quality and tannin content of two provenances of Calliandra calothyrsus Meissner. Journal of the Science of Food and Agriculture, 80(10), 1461-1468.

77. Tabacco, E., Borreani, G., Crovetto, G. M., Galassi, G., Colombo, D., \& Cavallarin, L. (2006). Effect of chestnut tannin on fermentation quality, proteolysis, and protein rumen degradability of alfalfa silage. Journal of Dairy Science, 89(12), 4736-4746.

78. Terrill, T. H., Rowan, A. M., Douglas, G. B., \& Barry, T. N. (1992). Determination of extractable and bound condensed tannin concentrations in forage plants, protein concentrate meals and cereal grains. Journal of the Science of Food and Agriculture, 58(3), 321-329.

79. Theodoridou, K., Aufrère, J., Andueza, D., Pourrat, J., Le Morvan, A., Stringano, E., \& Baumont, R. (2010). Effects of condensed tannins in fresh sainfoin (Onobrychis viciifolia) on in vivo and in situ digestion in sheep. Animal Feed Science and Technology, 160(1), 23-38.

80. Treutter, D. (2006). Significance of flavonoids in plant resistance: a review. Chemistry Letters, 4(3), 147.

81. Ulyatt, M. J., MacRae, J. C., Clarke, R. T. J., \& Pearce, P. D. (1975). Quantitative digestion of fresh herbage by sheep: IV. Protein synthesis in the stomach. The Journal of Agricultural Science, 84(3), 453-458.

82. Wang, Y., Douglas, G. B., Waghorn, G. C., Barry, T. N., Foote, A. G., \& Purchas, R. W. (1996). Effect of condensed tannins upon the performance of lambs grazing Lotus corniculatus and lucerne (Medicago sativa). The Journal of Agricultural Science, 126(1), 87-98.

83. Waghorn, G. C., Ulyatt, M. J., John, A., \& Fisher, M. T. (1987). The effect of condensed tannins on the site of digestion of amino acids and other nutrients in sheep fed on Lotus corniculatus L. British Journal of Nutrition, 57(1), 115-126.

84. Waghorn, G. C., Shelton, I. D., \& McNabb, W. C. (1994).
Effects of condensed tannins in Lotus pedunculatus on its nutritive value for sheep. 1. Non-nitrogenous aspects. The Journal of Agricultural Science, 123(1), 99-107.

85. Waghorn, G. C., \& McNabb, W. C. (2003). Consequences of plant phenolic compounds for productivity and health of ruminants. Proceedings of the Nutrition Society, 62(2), 383-392.

86. Waghorn, G. C. (2008). Beneficial and detrimental effects of dietary condensed tannins for sustainable sheep and goat production-Progress and challenges. Animal Feed Science and Technology, 147(1), 116-139.

87. West, J. W., Hill, G. M., \& Utley, P. R. (1993). Peanut skins as a feed ingredient for lactating dairy cows1. Journal of Dairy Science, 76(2), 590-599.

88. Woodward, S. L., Laboyrie, P. J., \& Jansen, E. B. L. (2000). Lotus corniculatus and condensed tannins-effects on milk production by dairy cows. Asian-Australasian Journal of Animal Science, 13, 521-525.

89. Zhu, J., Filippich, L. J., \& Alsalami, M. T. (1992). Tannic acid intoxication in sheep and mice. Research in Veterinary Science, 53(3), 280-292. 


\section{Tanini in njihov vpliv na učinkovitost proizvodnih lastnosti pri prežvekovalcih}

\section{IZVLEČEK}

V zadnjih letih so v številnih publikacijah proučevali učinkovitost fitogenih krmnih dodatkov, rastlinskih krmnih dodatkov, $\mathrm{v}$ živalski prehrani za izboljšanje produktivnosti živali in kakovosti njihovih proizvodov. Pri prehrani prežvekovalcev se raziskave zelo pogosto osredotočajo na usodo beljakovin in produktivnost kot posledico uporabe s tanini bogatih rastlinskih ektraktov in rastlinskih delov. Večina študij, povezanih $s$ tanini, se ukvarja s preučevanjem krme, predvsem metuljnic, manj je znanega o taninskih ektraktih. Tanini so fenolne sekundarne spojine, ki se naravno pojavljajo v rastlinah kot njihova zaščita pred rastlinojedi, obramba pred patogeni ter za ohranjanje energije in dušika. Tanini so pri prežvekovalcih dolgo časa veljali za antinutritivne spojine, vendar pa nove sistematične študije povezujejo tanine s koristnimi vlogami pri prehrani in zdravju živali. Nove študije natančneje razlikujejo različne skupine taninov. Krma, ki vsebuje hidrolizirajoče ali kondenzirane tanine, posledično učinkuje na upočasnitev prebave beljakovin, povečavo sinteze mikrobnih beljakovin v vampu in zmanjšanje metanogeneze. Poročali so o pozitivnih učinkih na zdravje živali, kot je preprečevanje napenjanja in pojava parazitov. Kadar tanine krmimo v ustrezni količini, lahko le-ti posledično vplivajo na izboljšane proizvodne lastosti, kot so večji prirasti, večja prireja mleka ter boljša sestava mleka. Njihova vloga se šteje za vse bolj pomembno v uporabi kot krmni dodatek pri številnih krmnih mešanicah za prežvekovalce.

Ključne besede: hidrolizirajoči tanini, kondenzirani tanini, proizvodne lastnosti prežvekovalcev 